\title{
Application of Criminal Liability Based on the Principle of Errors In the Narcotics Case Court Decision
}

\author{
Herlina Manullang ${ }^{1}$, Marthin Simangunsong ${ }^{2}$ \\ Departement of Criminal Law Nommensen of University, \\ Indonesia1, Departemen of Criminal Law \\ Nommensen of University, Indonesia \\ herlinamanullang63@gmail.com1, Marshim61@gmail.com
}

\begin{abstract}
Nowdays narcotics consumption in Indonesia has reached a serious and concerning level. There isn't one area in Indonesia have a free title from narcotics black market. The spirit of eradicating narcotics is carried out through the prohibition and eradiction through law No.35 of 2009 which severse criminal sanctions that are more severse than the previous law that is law No. 22 of 1997. The interested in Law No. 35 of 2009 about Narcotics by injecting "principle of errors" in the trunk of his body being used as a basis for imposing penalties on perpetrators, as known the principle of actus non facit reum, nisi mens sit rea in criminal law. Therefore, judges are prohibited from imposing criminal sanctions or sanctioning actions on the defendant if their mistakes are not proven. By following the principle of errors, proven narcotic crime does not automatically the culprit to be convicted, because it depends on whether the defendant has a mistake or not. Based on 3 (three) court decisions examined, most of the defendants were convicted when the crime was committed. In other words, the defendant's mistake is automatically there and the crime is proven. However, between crime and error are two different areas that require proof of each.
\end{abstract}

Keywords: Application, Criminal Liability, The Principle of Errors

\section{Itroduction}

Indonesia still puts the eradication of narcotic crime as one of the top priorities in law enforcement. At least the government's efforts can be seen from the Narcotics Act 35 Year 2009 about Narcotic (hereinafter referred to as narcotic LAW) that contain much heavier criminal sanctions compared to the legislation previous. Previously, criminal provisions on narcotic crimes were governed by 2 Laws, namely Law No. 5 of 1997 about Psychotropic (hereinafter referred to as Psychotropic Law) and Law 
No. 22 of 1997 about Narcotics. The seriousness of Indonesia to eradicate the dark circulation is also reflected in The Presidential Instruction No. 6 of 2018 about The National Action Plan for the Prevention and Eradication of Narcotics and Drug Circulation (P4GN) of 2018-2019. Through this movement "Indonesia of Drugs Free". The severity of the war on drugs turned out to have not brought significant changes to the loss of drug circulation and at the level of use or abuse of narcotics. Based on narcotics observation and illegal drugs (drugs), nowadays is no longer circulating in the big cities, but the circulation has penetrated into districts, subdistricts and villages. Its use is not only among those who have money only, but also has penetrated the community of middle and lower economy class.

Likewise, people who consume it are not only teenagers, but from children to older people. The government has conducted a policy to make war on narcotics, among others, in the form of death criminal sanctions, imprisonment, ironically have not brought significant improvement to lower the dark circulation figures or narcotic abuse. Narcotic criminal acts have been categorized as transnational crimes or often called crime.

In addition, the Drug syndicate network has been very so capable and able to conceal drugs. The amount of international attention in the prevention and eradication of Narcotics has encouraged the United Nations to issue the United Nations Convention on Transnational Organized Crime which has been ratified by the law Number 5 year 2009 on the endorsement of United Nations Convention against Transnational Organized Crime (UNTOC).

Under the UNTOC Convention, narcotic criminal acts are categorized as organized transnational crimes. The definition of narcotics pursuant to Article 1 UU No. 35 of 2009 is Narcotic is a medicinal substance derived from plants, both synthetic and semis synthesis that can cause a decline or change of awareness of loss of taste, reduce to eliminate pain, and can cause dependence, which is distinguished into the groups as enclosed in this law.

Narcotics criminal offence is a serious criminal offence and needs attention from law enforcement officers, governments and the public. Seeing the development of this highly worrying narcotic criminal offense, in turn demanded an improvement in the field of law enforcement. The principle of error is the basis for prosecution of legal subjects.

That is, to be able to impose a criminal against the perpetrators (Wardana, $2017: 35$ ) in addition to proven elements of a criminal offense, the offender must also be proven guilty. The proof of this error element is sometimes not easy to do especially against narcotic crimes. The interesting thing is Law No. 35 of 2009 about Narcotics with injected "principle of error" in main law by serve as the basis to impose a criminal to the perpetrator, as known the principle of actus non, facit reum nisi mens sit rea in 
criminal law. In compliance with this, judges are forbidden to impose criminal sanctions or action sanctions on the defendant if the principle of "guilt" is not proven. By following the principle of error, the evidence of narcotic crime is not automatically the perpetration of being sentenced to criminal or action, because it depends whether the defendant has an error or not.( Ratna, 2017 : 11) However, it is unfortunate that when formulates the Drug Law that does not contain the element "with the intent" or "deliberately" in its criminal articles; it is often erroneously interpreted as part of the rule of law that adheres to the concept of absolute liability or "strict liability"( Amrani and Ali, 2015: 217.).

This situation certainly causes a pile of narcotics criminal act that is not in accordance with the soul of the narcotics law containing the principle of error. In this circumstance, the judge should still uphold the principle of innocent presumption and punish the person after removing any physical doubts that exist on the basis of the facts it unfolds. The following are examples of narcotic criminal acts that are far from considering the perpetrator's fault as an example of the case of Supreme Court appeal No. 1614 K/Pid. Sus/2012 and the decision of the cassation number 1531K/Pid. Sus/2010 on behalf of Rudy Ket San, eventually The Supreme Court has freed both narcotics convicted of the District Court and the High Court. In practice in the judiciary is not uncommon an indicted who performs narcotic criminal acts such as narcotics control directly sentenced to criminal fact the law of the trial shows the defendant did not touch the narcotic, negatively used narcotics and no other witnesses other than investigators were presented to the court. The question, on the basis of what the judge believes that the defendant proved to be master narcotics and convicted of it so that the criminal is dropped according to the theory of separation between criminal acts and mistakes? The practice of law enforcement to prove the element of error in this narcotic criminal act is very difficult so that not infrequently the public prosecutor or judge silently silence the principle of error in terms of proof. In this state the public prosecutor or judge does not use a strict liability system. Law enforcement practices such as these are very clearly contrary to the Narcotics Act which adheres to the principle of error.

\subsection{Significance of the study}

Along with the social change and the development of science and technology has brought influence on various lives, no exception of criminal law. In the development of the very significant criminal law thought is the development of a criminal liability system adapted from the principle of fault to the principle of absence of fault. The legislative policy of establishing a criminal liability system is largely still adhering to the system of criminal liability based on the strict principle of error even though limited in certain criminal acts has been recognized liability without fault, for example a corporate criminal liability system. Lawmakers' doubts may be caused by the criminal code still adhered to strict error principle. If this policy is retained, it will have consequences on the effectiveness of law enforcement, which in turn will impact the crime prevention 
completely and perfectly.

\subsection{Scope and Limitation of the study}

The application of criminal liability in narcotic crime is not only done by matching the defendant with the elements delict in the law, but the judges must be on the subject of the requirements of the pipetting set forth in the Narcotics Act.

\subsection{Setting of the study}

Criminal liability is defined as the passing of objective unwillingness that exists in criminal acts and is subjective, qualified to be punished for his actions (Saleh, 1982: 33). The intent of objectively is that one's deeds are prohibited. The indicator is that the act is against the law, either in the sense of the formal law or the law of Material, while the intent of subjective misconduct refers to the person who performs the forbidden deed. Even if a person's forbidden deed has been made, but if not, the individual cannot be reproached because there is no fault, criminal liability is not possible. Criminal liability may not be created if the person who commits a criminal offence does not have a mistake, then the fault becomes the central point of the criminal liability, so in this state the fault is one of the characters impossible criminal law may be removed (Finn, 1996 : 548) Under these circumstances, apply actus non facite reum, nisi mens sit rea. In practice, the application of the principle will rigidly complicate the process of proof in some criminal acts. Furthermore Remmelink argues that the evidence of criminal acts is not automatically the culprit will be sentenced so that the country has a theoretical justification of dropping a criminal to someone who proves to commit a criminal offense, on the person there is an error (Remmelink, 2003; 142)

\section{Research Design And Methodology}

This writing is done by using a research method of doctrinal law or normative juridical research (legal research) by conducting an analysis of the problem through the approach of legal principles and referring to the norms In the legislation, international conventions, tracts, court decisions and norms that live in society (Soekanto and Mamudji 2010:12). Normative legal research is a study commonly used in the development of legal sciences commonly referred to as dogmatic law (Sidharta 2011:142). As stated by Peter Marzuki, the scope of legal issues in dogmatic law is a practical aspect of legal science, that is: First: the occurrence of the multitasking against the regulatory text; Second, there is a legal void; Third, there is a difference in the interpretation of facts (Marzuki 2007:57-61). Based on the type of normative juridical research, the statute approach and case approach are used to analyze this research. The specification in this study is the discoveries of law In 
Concreto with secondary sources of legal material that can be in the specification include primary, secondary and tertiary data. The method of presenting the legal substance is done by categorizing, displaying and analyzing in a qualitative normative manner by using grammatical, systematic and theological interpretation.

\section{Findings And Conclusions}

The basis of the implementation of criminal liability in Law 35 of 2009 about Narcotics is a mistake. In the narrow sense of the error can be in the form of deliberate (opzet) or negligent (culpa). Talking about mistakes means discussing criminal liability that criminal liability is the fundamental basis of criminal law, so according to Idema (Sudarto, 1991: 41) is the heart of criminal law. This indicates that the basic responsibility of the person is placed in the concept/rationale to prove whether the elements of criminal action. This means that if the elements are proven to be criminal, it is also evident that their mistakes are punished by themselves. This means that criminal liability is attached to criminal acts (Kanter and Sianturi, 1982 : 161). The application of criminal liability in the case of No. 2091/Pid. B/2013/PN. MDN against defendant Yudi Hasmi Siregar, the defendant has also been indicted to commit narcotic crimes in the form of "without right and against the law of owning, storing, or Provide narcotics category I (one) not the plant weighs more than 5 (five) grams of weighing 6,582.3 grams. In proving the element of "owning or storing narcotics category I (one) not plant weighs more than 5 grams, the judges judge as follows: Considering that based on the testimony of Matthew Kurniawan and Dendi Susanto on Tuesday the 29th May 2013 and Tim BNN RI has made an arrest against Salmon alias Budi on Jl. Setia Budi Medan, North Sumatra methamphetamine is getting a narcotics category I type of methamphetamine with a weight of 21 grams and after the introduction of Salmon aka Budi said that he get methamphetamine from the defendant:

CONSIDERING, that further witnesses of Matthew Kurniawan and Dendi Susanto and Tim from BNN RI went to the yellow shop in Jl. Colonel Sugiono Medan directly up to the 2nd floor and found a locked room equipped with CCTV, then the room Was put down and found narcotics evidence type of methamphetamine with gross weight 6,582.3 gram and tablets/pills in gray with a logo "head of the Rabbit/Playboy" as many as 47 grams and white and red powder with a gross 178.4 gram that is inserted in the Cardboard under the seat in the room and at the time, the other officers managed to arrest the defendant and a witness of the Martunis alias of Tunis in a decayed.

CONSIDERING, that based on the news of the laboratory event No. 138. F/VI/2013/UPT LAB TEST dated June 11, 2013 obtained the result that the evidence 
of crystal with gross weight $6,582.3$ grams has been set aside for the destroyed gross weighing 6,512, 3 grams and tested In laboratory weighing 70 grams is true contains Methamphetamine and listed in category I (one) sequence number 61 Appendix of Law RI No. 35 of 2009 concerning narcotics.

CONSIDERING, that based on the Official Report on Labor No. No.138.F / VI / 2013 / UPT UJI Lab dated June 11, 2013, it was found that the evidence in the form of crystal with a gross weight of 6,582.3 grams had been set aside to be destroyed 6,512.3 grams gross weight and tested 70 gram weighing is true containing Methamphetamine and registered in category I (one) sequence number 61, Attachment of Republic of Indonesia Law No. 35 of 2009 concerning Narcotics. The legal considerations above state that the defendant is proven to have committed acts in the form of possessing or storing narcotics of category I (one), not plants. In connection with the meaning of owning and storing this legal counsel the defendant states that "the sentence of possessing, storing or providing narcotics" in Law No. 35 of 2009 must mean the fulfillment of two elements when the narcotics object is in the hands of the suspect / defendant, both elements are "power on an object" and the willingness to own the object and these two elements must be related to the facts of the trial that clearly revealed "bezit" for methamphetamine as evidence at the trial there is a person named Alm. Salmon alias Budi was obtained from Ahua (DPO) and Ame (DPO) so that it is obvious that the burden of liability and legal responsibility is charged to the defendant.

The defendant's legal counsel was rejected by the judges without a clear reason for refusing. The tribunal declares that The Tribunal does not agree with plea legal counsel defendant about to be intended to fulfill two elements when the narcotic object was in the hands of the suspect/defendant, as has been considered above, so the plea legal counsel defendant must be rejected. The statement of the Tribunal is essentially not to be referred to as a rejection because it is not described the argument of rejection. When the tribunal rejects the opinion of the defendant's legal counsel, it must be clearly and in detail the rejection accompanied by the argument. When the tribunal rejects the defendant's opinion of legal counsel, it should be explained clearly and in detail the rejection is accompanied by adequate argumentation. Unfortunately, this is not found in this ruling. Concerning the unauthorized proof of the substance or against the law, the argument of the judges in the case of narcotics criminal offence has permission from the Minister of Health to use narcotics category I (one) methamphetamine in limited quantities in the interest of Science, Technology and Reagents Diagnostic.

After the objective is without the right and the rule of law has and deviated narcotics category I (one) is not a proven plant, the judge then declares that the defendant guilty to conduct narcotics criminal offence referred to in Article 12 paragraph (2) Narcotic Law, but the defendant's fault has not been proven. The Tribunal has the view that because the objective element is proven, and because the subjective elements of 
deliberate intent or mischief are not included as part of the delic element, the accused fault itself is evident. If noted carefully, the Tribunal should still have to prove the defendant's fault by interpretation of the facts of the law revealed that the defendant owns and stores the methamphetamine weighing 6,582.3 grams. Moreover, when arrested, the defendant was using a methamphetamine in his room. These two things should be considered by the judges so that the conclusion is that it is impossible if deliberate intent is not present in the defendant while committing a forbidden deed.

In the verdict No 124/Pid.Sus/2011/PN. SLMN, with the defendant Priyatni, he was shown to commit a criminal offence without right or against the law having, storing, mastering or providing narcotics category I (one) not a plant that weighs more than 5 grams ie in casu Heroin stored inside the soles of the boots and inside the buste hounder (BH) with a cloth wrapped in 1,047 grams. As with the verdict No. 2091/Pid. B/2013/PN. MDN, the judges in this case also did not prove the defendant's fault, which is merely that the defendant proved to possess or save heroin weighing 1,047 grams against the law/without rights. The facts of the law in the laws that support the evidence of such elements, among others; Firstly, the defendant brought the heroin from Malaysia to Jogjakarta without being accompanied by official documents from the competent authorities; Secondly, the defendant brought the heroin in a way hidden in the soles of sandals shoes and buste hounder (BH) she used; Third, based on the test results Forensic cab Laboratory, Semarang dated July 12, 2011 items found by the Customs and excise officers of Adisucipto Airport Jogjakarta in the flip soles and buste hounder (BH) actually heroin registered in the Narcotics category I (one) sequence No. 19 Appendix Law No. 35 of 2009 about Narcotics. The Tribunal judges that the defendant's fault by itself proved to be proven by his conduct. In addition to being impossible if the defendant, based on the three facts of the law above, did not know that the goods are heroin and do not want to take them from Malaysia to Jogjakarta. There are three reasons that can be expressed based on the legal fact at the trial. Firstly, when the defendant was sung a pair of brown sandals and $\mathrm{BH}$ by Cukudi, a citizen of Malaysia, at Hotel Indigo, Malaysia, he actually knew that in sandals and buste hounder (BH) there was heroin. Secondly, the defendant to Malaysia was indeed from the beginning to bring the heroin to the order of Irvan Rivandi, and for his efforts he gained a money reward of Rp 5 million. Third, who told the defendant to sleep at Hotel Indigo while in Malaysia was Irvan Rivandi. These three things show that the defendant did possess and had a heroin weighing 1,047 grams from Malaysia to Jogjakarta deliberately, but it did not need to be proved. This means, the doctrine that brings together mistakes and criminal liability or the known teachings of monism followed by the Assembly of judges. This doctrine is clearly outlined in one of its legal considerations, among others: Considering that as outlined in consideration of the element above that during the examination at the conference against the defendant, there is no excuse for forgiving or excuse the reason that can remove the liability Criminal liability, then against the defendant must be convicted of a criminal with his actions. Based on the legal consideration, the reason for forgiving and truism is the reason that it can remove criminal liability is essentially closely related to the teachings of Monism, where this teaching does not 
separate the criminal act and Defendant's fault. Mistakes are considered to be proven by the evidence of criminal acts.

\section{Recommendations}

Theoretically, the judge at the time of giving legal consideration by stating the defendant is guilty of committing a criminal offence, so that it can be sentenced. First, Legal consideration the judge's decision should pay attention to the indictment and relate to the facts revealed in advance of the trial. The indictment is a concrete decomposition of criminal acts committed by the defendant to be associated with the legislation, and then the fault has not been considered the judge only considers proven "good deeds" Do or do not make and infill as a result of the prohibited laws. If attributed to the concept of criminal liability, the judge at the first stage proves "the objective reprobate of the criminal act". Secondly, if the consideration of the worrying is fulfilled based on the instrument of evidence that makes the judge believe there is no doubt in that deed is a criminal offence and the defendant does, then the consideration continues at the at the qualification stage. At this stage the judge considers the defendant's fault comprehensively, either internal conditions, a sign of guilt (intentional or mischief) and a normal state of the situation. The judge considers qualifying the form of an error that occurs, up to qualifying the defendant's fault pattern. When associated with the concept of criminal liability, the judge at the second stage proves "subjective that there is qualified to be convicted because of his actions". These two things are not used consistently by judges in considering whether the defendant is found guilty of narcotic criminal offence. Of the 2 court decisions above, defendants were convicted when the criminal act was committed by the defendant proved. Thus the defendant's fault is automatically present and the evidence of a criminal offence. Criminal acts and offences are two distinct areas that require proof of their own.

\section{References}

Amrani, H and Ali M,(2015),Sistem Pertanggungjawaban Pidana, Perkembangan dan Penerapan, Rajagrafindo Persada, Jakarta, pp 217.

Kanter E,Y and Sianturi, 1982, Asas-Asas Hukum Pidana di Indonesia dan Penerapannya , Alumni AHEAM-PTHAEM, Jakarta, pp 161

Finn. H. C, (1996), The Responsible Corporate Officer, Criminal Liability, and Mens Rea : Limitations on the RCO Doctrine", The American University Law Review, Vol.46. hal.548

Remmelink, (2003), Hukum Pidana Komentar atas Pasal-Pasal Terpenting dari Kitab Undang-Undang Hukum Pidana Belanda dan Pandanannya dalam Kitab 
Undang-Undang Hukum Pidana Indonesia, Gramedia Pustaka Utama, Jakarta, pp. 142.

Ratna WP, (2017), Aspek Pidana Penyalahgunaan Narkotika Rehabilitasi Versus Penjara (Menyoroti Pasal 127 UU No.35 Tahun 2009), Yokjakarta, pp 11.

Saleh.R.(1982),Pikiran-PikiranTentang Pertanggungjawaban Pidana, Ghalia Indonesia, Jakarta, hal. 33

Soekanto,S and Mamidji S, (2010), Penelitian Hukum Normatif, Rajawali Press, Jakarta, pp 12

Sidharta A.B (2011), Ilmu Hukum Indonesia Upaya Pengembangan Ilmu Hukum Sistematik Yang Responsif Terhadap Perubahan Masyarakat, Genta Publishing, Jakarta, pp 142

Sudarto (1991), Hukum Pidana I, Yayasan Sudarto Universitas Diponegoro, Semarang, pp. 41

Marzuki P.M (2007), Penelitian Hukum, Kencana, Jakarta, pp 57-61)

Wardana, Rinto, (2017), Tanggungjawab Pidana Kontraktor Atas Kegagalan Bagunan, MNC, Jakarta, pp 35.

Cynthia H.Finn, 1996, The Responsible Corporate Officer, Criminal Liability, and Mens Rea : Limitations on the RCO Doctrine", The American University Law Review, Vol.46. hal.548 